\title{
RAKYAT DALAM GOOD CORPORATE GOVERNANCE: POSISI, HUBUNGAN, DAN SKEMA KEADABAN
}

Oleh: Imam Samroni*

\section{Abstract}

The relationship between state executor, business actor, and people or social order that enter Good Corporate Governance and Corporate Social Responsibility on an agenda is not necessaryly in an mutual acord. The papper offers three schemes in strengthening the position and relationship of the people or social order among other stakeholders. Firstly, the attitude toward neoliberalism, which is the scheme to prepare the people or the social order using future research in managing the future. Secondly, the scheme of democracy choice that has been a must in the reason economic-politic conditions. And thirdly, the attitude toward "memetic engineering," wich is the scheme to develop populist values parallel with nation plurality that they are accepted and are not constanly put in a contradiction.

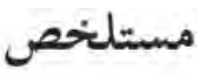

السلطة التنفيذية، القطاع الخناص، و النظام البحتمعي أو الجماهير هي أطراف ثلائة

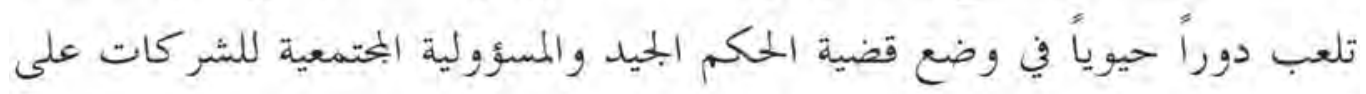
أجندة الإصلاح السياسي .إن العلاقة بين تلك الأطراف الثلاثة لا تبدو متناغمة بالضرورة .تطرح الورقة الحالية ثالثة نماذج يمكن من خالالما دعم مكانة الجماهير في عالافتها من المكونين الآخرين .الأموذج الأول يقوم على فكرة النيوليبرالية عبر وسيلة الدراسات المستقبلية نحو رفع جهازية الجماهير لإدارة مستقبلها .الأنموذج

Mantan Anggota DPRD Yogyakarta dari Partai Keadilan Sejahtera; e-mail: im_samroni@yahoo.com. 


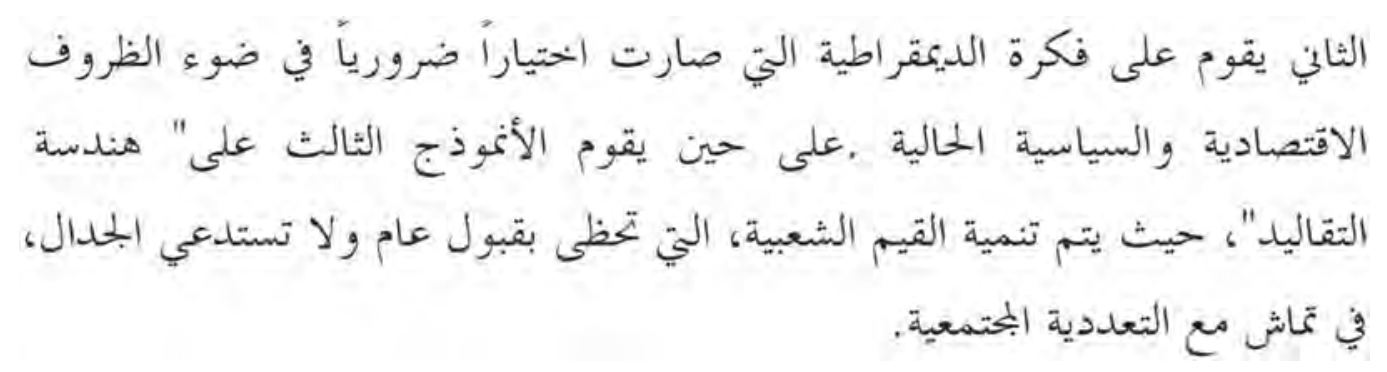

Keywords: GCG, CSR, neoliberalisme, rakyat, keadaban

\section{A. Pendahuluan}

Keadaan Indonesia dewasa ini menegaskan kembali tentang pentingnya kebijakan tata kelola perusahaan yang baik (Good Corporate Governance/ GCG). GCG mensyaratkan peningkatan kemampuan dan pengetahuan pembangunan. Tata kelola kehidupan berbangsa dan bernegara dipahami secara antisipatoris dan diangkat dari bahasa keseharian rakyat untuk hidup (bertahan hidup) serta ditarik secara inferensial dalam budaya neoliberalisme. Hal ini menyangkut kapasitas bangsa untuk belajar, yaitu kemampuan untuk mengelola informasi-informasi baru. Konsep ini diajukan Soedjatmoko, yang oleh Mochtar Buchori dikembangkan menjadi kekuatan pendidikan nasional, yaitu kemampuan bangsa untuk menyelesaikan masalah pendidikan dewasa ini secara relevan. ${ }^{1}$

Tulisan ini bertujuan untuk memberikan dan menyigi sistem GCG yang dipertautkan dengan tanggung jawab sosial perusahaan (Corporate Social Responsibility/ CSR). Pertautan antara GCG dan CSR tersebut diletakkan dalam budaya neoliberalisme, yaitu untuk memetakan posisi dan hubungan rakyat bersama pemangku kepentingan yang lain. Berdasarkan kajian terhadap posisi dan hubungan rakyat tersebut, penulis mengajukan skema keadaban.

\section{B. Hubungan serta Prinsip Dasar GCG dan CSR}

GCG adalah definisi teknis dalam praktik ekonomi yang telah menjadi bahasa pemerintahan. Istilah lain yang lazim digunakan adalah good public governance, good government governance, good nation governance, atau good civil governance. ${ }^{2}$

1 Mochtar Buchori, Pendidikan dalam Pembangunan, (Yogyakarta: Tiara Wacana kerjasama dengan IKIP Muhammadiyah Press, 1994). hal. 2-3,8.

2 FA Alijoyo, "Trildgy of Governance (I) Corporate Governance," Republika, 10 Maret 2004a. 
Kosa kata ini dipopulerkan ketika pada 1997-an perusahaan-perusahaan besar di Indonesia ambruk, sebagai preseden krisis moneter, karena tidak patuhnya manajemen perusahaan terhadap prinsip-prinsip GCG. ${ }^{3}$

Kebijakan GCG muncul akibat pemisahan antara kepemilikan dan pengelolaan perusahaan. Pemisahan ini memberi kewenangan kepada pengelola (manajer/direksi) untuk menjalankan perusahaan, seperti mengelola dana dan mengambil keputusan perusahaan atas nama pemilik. Mas Achmad Daniri mendefinisikan GCG sebagai:

“... tata kelola perusahaan yang memberikan jaminan berlangsungnya sistem dan proses pengambilan keputusan organ perusahaan berlandaskan pada prinsip keadilan, transparan, bertanggung jawab, dan akuntabel. Dalam proses pengambilan keputusan, organ perusahaan ini juga terkait dengan stakeholders perusahaan, seperti kreditor, pemasok (supplier), masyarakat, konsumen, pemerintah, media, dan lembaga swadaya masyarakat."4

Dalam klaim pemerintahan, GCG adalah komitmen dan konsistensi para penyelenggara negara untuk menjaga kepercayaan publik melalui transparansi dan akuntabilitas yang layak dipertanggungjawabkan. Sedangkan bagi pelaku bisnis, GCG adalah kriteria untuk membangun kapasitas perusahaan dengan standar global melalui integritas serta kecakapan dan proses pengambilan keputusan yang berasas transparansi serta akuntabilitas.

Terdapat prasyarat untuk suksesnya penerapan GCG, yaitu sinergisitas antara pihak penyelenggara negara (legislatif, eksekutif, dan yudikatif), komunitas bisnis (terutama perusahaan publik dan BUMN), serta rakyat (terutama Lembaga Swadaya Masyarakat, Civil Society Organizations, ${ }^{5}$ dan media massa). Sinergisitas dimaksud, merujuk FA Alijoyo, adalah dengan konvergensi yaitu membesarnya lingkaran dan

3 Agus Subagyo dan Imam Samroni (ed), Hasanuddin Yusuf: Meretas Jalan Menuju Pengabdian Bagi Pemuda, (Yogyakarta: LSKPD, 2005), hal. 22-26.

4 Mas Achmad Daniri, "Membudayakan 'Good Corporate Governance," Kompas, 15 April 2004.

5 Pembedaan LSM (Lembaga Swadaya Masyarakat) dan Civil Society Organizations(CSO) mengacu pendapat Agus Subagyo, pegiat Lembaga Studi Kebijakan dan Pemberdayaan Daerah, dalam perbincangan pribadi pada 20 Mei 2006. LSM adalah lembaga yang dalam pendampingan masyarakat mau dan telah menerima dana CSR dari korporat terutama asing, sedangkan CSO masih independen bersama keswadayaan masyarakat serta menolak jasa baik CSR. Dalam klaim pegiat CSO, pencarian dana LSM menimbulkan ketergantungan masyarakat, menjadi agen neoliberalisme, dan menegasi cita-cita masyarakat madani yang diperjuangkan. Pasca-gempa DIY, 27 Mei 2006, pembedaan ini menjadi ideologis ketika sejumlah CSO memboikot agenda LSM. 
meluasnya irisan ketiga elemen tersebut. Sebaliknya, dibutuhkan rekayasa agar masing-masing elemen tersebut tidak memencar dan berjalan sendiri-sendiri tanpa arahan yang jelas serta terfokus. ${ }^{6}$

Lebih lanjut, FA Alijoyo mendeskripsikan bahwa Governance dalam perspektif penyelenggara negara (good government governance, good governance) adalah pelaksana kewenangan politik, ekonomi, dan administrasi untuk mengelola urusan bangsa, mekanisme, proses, serta hubungan antar warga negara dan kelompok kepentingan. Hal ini sebagai jaminan terlaksananya hak dan kewajiban warga serta menengahi atau memfasilitasi jika terjadi perbedaan kepentingan. Penyelenggara negara mempunyai tiga pilar yaitu economic governance, political governance, dan administrative governance. Economic governance meliputi proses pembuatan keputusan yang mempengaruhi ekonomi negara baik langsung maupun tidak langsung. Political governance merujuk pada proses pembuatan keputusan dan penerapan kebijakan negara secara absah, baik di tingkat legislatif, eksekutif, dan judikatif. Sedangkan administrative governance merupakan sistem penerapan kebijakan yang memungkinkan sektor publik berjalan efisien, tidak memihak, akuntabel, serta terbuka.

Governance dalam perspektif pelaku bisnis -yaitu himpunan perusahaan yang beroperasi di bidang industri barang dan jasa -mempunyai pengaruh langsung terhadap kebijakan sosial, politik, dan ekonomi, dengan rekayasa lingkungan bisnis yang lebih kondusif bagi pasar serta perusahaan itu sendiri. Terdapat kecenderungan adanya seperangkat peraturan yang memaksa pelaku bisnis untuk tidak kebal lagi terhadap batasan tradisional geografis dan negara. Hal ini merupakan tuntutan tanggung jawab perusahaan untuk menghasilkan keuntungan bagi pemilik modal dan para pemangku kepentingan lain.

Dalam hubungan inilah pelaku bisnis mengapresiasi governance sebagai GCG. ${ }^{7}$ GCG merupakan struktur, sistem, serta proses bagi pelaku bisnis untuk memberi nilai tambah perusahaan secara berkesinambungan dan untuk jangka panjang bagi pemegang saham. Sebagai struktur, GCG mengatur hubungan antara dewan komisaris, direksi, pemegang saham, dan para pemangku kepentingan lain. Sebagai sistem, GCG menjadi dasar mekanisme pengecekan dan perimbangan kewenangan atas pengendalian perusahaan yang dapat membatasi peluang pengelolaan yang

6 FA Alijoyo, “Trilogy of Governance (II)," Republika, 5 Mei 2004b.

7 FA Alijoyo, Trilogy of Governance (I)..., ibid. 
salah maupun terjadinya penyalahgunaan aset perusahaan. Sedangkan sebagai proses, GCG memastikan tranparansi dalam proses penentuan tujuan perusahaan, pencapaian, dan pengukuran kinerjanya.

Governance dalam perspektif masyarakat disebut societal governance atau society, yang merupakan himpunan pribadi atau kelompok (berorganisasi maupun tidak) serta berinteraksi secara sosial, politik, dan ekonomi dengan aturan formal maupun informal. Society meliputi LSM, CSO, organisasi profesi, dan kelompok kepentingan lain. Menurut Bob S Hadiwinata, dalam Bonnie Setiawan, society telah menjadi "Sektor Ketiga," yaitu sektor publik yang mengedepankan kepedulian sosial atau personal. ${ }^{8}$ Sektor Ketiga ini beroperasi di luar penyelenggara negara dan pelaku bisnis, yaitu melalui akses ke organisasi akar rumput serta mempunyai komitmen kepada kelompok terabaikan.

Berdasarkan paparan tersebut, penyelenggara negara, pelaku bisnis, dan masyarakat merupakan kesatuan yang secara ideal mengada-bersama. Ketiganya mempunyai kedudukan, peran, serta fungsi dan tidak akan mampu berdiri serta berkembang sendiri-sendiri. Sinergisitas ketiganya merupakan keseimbangan dan garansi pelaksanaan GCG. Keberhasilan penerapan GCG di pihak pelaku bisnis membutuhkan penyelenggara negara dan CSO yang konstruktif, dengan insentif moral serta kontrol terhadap pelaku bisnis. Keberhasilan penerapan GCG dalam praktik penyelenggara negara meniscayakan peran dan fungsi pelaku bisnis dan CSO dengan tuntutan transparansi dan akuntabilitas dalam setiap prosedur serta metode pengambilan keputusan. Dalam perspektif CSO, peran ideal adalah dengan tetap mengedepankan partisipasi untuk fungsi kontrol dan penyeimbang.

Paparan di atas dapat disigi lebih mendalam bahwa terdapat prinsip-prinsip dalam GCG yaitu fairness (berkeadilan), transparency (akurat dan tepat waktu), accountability (pertanggunggugatan), dan responsibility (pertanggungjawaban). Menurut Sita Supomo, ketiga prinsip awal -yaitu fairness, transparency, dan accountability- lebih memberi penekanan terhadap para pemegang saham perusahaan (shareholders) sehingga ketiga prinsip tersebut lebih mencerminkan share holdersdriven concept. ${ }^{9}$ Sedangkan responsibility lebih menekankan pada kepentingan

8 Bonnie Setiawan, "LSM sebagai Kekuatan Sosial Baru," Kompas, 17 April 2004. Sektor Pertama adalah penyelenggara negara yang berkewajiban menjamin pelayanan bagi warga negara dan menyediakan kebutuhan sosial dasar, sedangkan Sektor Kedua adalah pelaku bisnis yang bertujuan mencari penghidupan dan menciptakan kekayaan.

9 Sita Supomo, "Corporate Social Responsibility (CSR) dalam Prinsip GCG," Republika, 20 Oktober 2004. 
stakeholders perusahaan, yaitu menciptakan nilai tambah dari produk dan jasa serta memelihara kesinambungannya (stake holders-driven concept). Pemangku kepentingan perusahaan adalah para pihak yang berkepentingan terhadap keberadaan perusahaan, yaitu karyawan, pelanggan, konsumen, pemasok, masyarakat, dan lingkungan sekitar, serta pemerintah selaku regulator.

Prinsip responsibility dari GCG membawa konsekuensi lebih lanjut tentang pentingnya CSR bagi pelaku bisnis tentang peran serta perusahaan dalam mewujudkan tanggung jawab sosial. Artinya, di samping prioritas keuangan, tanggung jawab perusahaan juga mencakup wilayah sosial dan lingkungan. Prioritas keuangan saja tidak cukup menjamin perusahaan untuk tumbuh secara berkelanjutan. Kasus pemboikotan warga terhadap produk barang dan jasa, perlawanan terhadap perusahaan, atau perusakan citra merupakan harga yang harus dibayar ketika perusahaan mulai dipermasalahkan konsumen.

Kecenderungan tersebut menegaskan bahwa perusahaan yang hanya memperhatikan sisi GCG tetapi melupakan aspek CSR hanya menjadi preseden dan investasi buruk. Terdapat tuntutan dan pengaturan untuk lebih memperhatikan lingkungan sosial dan ekonomi serta melaporkannya kepada pemangku kepentingan secara periodik. Dengan demikian, CSR sebagai praktik GCG merupakan pertanggungjawaban pelaku bisnis yang senyatanya memperkuat keberadaan bisnis itu sendiri. Kekuatan CSR terletak di dalam pemberdayaan masyarakat agar berpotensi sebagai konsumen sekaligus sasaran pelaku bisnis; ${ }^{10}$ gagasan besar yang menggerakkan budaya agung neoliberalisme.

\section{Neoliberalisme sebagai Dasar GCG dan CSR}

Kebijakan GCG dan CSR di dalam dirinya merefleksikan permasalahan mendasar secara kesejarahan saat praktik bisnis tumbuh, berkembang, dan berperan. Kajian tentang identitas, perubahan, dan krisis-krisis bisnis dewasa ini diniatkan sebagai upaya dasar untuk memahami kekuatan bisnis tersebut. Terdapat kecenderungan kuat, bahwa kajian tersebut berdasar pada gerak neoliberalisasi.

Neoliberalisme (selanjutnya ditulis: neolib), juga disebut ekonomi neoliberal, mengacu filsafat ekonomi-politik yang mengurangi atau menolak campur tangan pemerintah dalam ekonomi domestik. Paham ini berdasar metode pasar bebas,

10 B. Herry-Priyono, "Ekonomi dalam Lumpur," Kompas, 4 Oktober 2006; Jalal, "Menimbang CSR secara Rasional," Kompas, 16 September 2006. 
meminimalkan pembatasan terhadap pelaku bisnis, dan penghormatan hak-hak milik pribadi. Dalam kebijakan luar negeri, neolib adalah pembukaan pasar luar negeri melalui cara-cara politis, menggunakan tekanan ekonomi, diplomasi, dan/atau intervensi militer. ${ }^{11}$ Alih-alih mengabdi untuk kepentingan rakyat, praktik neolib tidak berimplikasi pada meluasnya ruang rakyat. Sebaliknya, menyempitnya ruang negara hanya berakibat pada perluasan ranah para pelaku bisnis selaku pemilik modal.

Sebagai suatu "isme", neolib merupakan visi tentang manusia dan masyarakat, dengan cara pikir ekonomi yang khas sebagai perangkat utama. Cara pikir tersebut meliputi pengandaian manusia dengan dimensi sebagai makhluk ekonomi. ${ }^{12}$ Selanjutnya, cara pikir serba ekonomi tersebut direntang untuk menjadi prinsip pengorganisasian seluruh masyarakat. Cara pikir ini berkembang menjadi hirarki prioritas, di mana sektor finansial yang tertinggi. Proses ekonomi bergerak dengan prioritas transaksi uang ketimbang produksi barang/jasa riil. Revolusi produk finansial pada 1980-an seperti derivatif, sekuritas, dan semacamnya, telah menjadi kecenderungan yang mempertajam perbedaan antara sektor virtual di atas sektor riil. Ambruknya pebisnis muslim, maraknya factory-outlet sebagai bazar produk China, pindahnya investor ke Vietnam, dan sebagainya telah menjadi permasalahan bisnis Indonesia yang klise.

Dalam perkembangannya, makna "bisnis" dalam konteks neolib telah menjadi rezim berbahasa, yang mampu menggerakkan, mengakomodasi, dan sekaligus menghukum para pelakunya. Pro-kontra dan alternatif peluang neolib telah menempatkannya sebagai kosakata yang paradoks. Terdapat perebutan penafsiran di mana praktik berbisnis bukanlah untuk dirinya sendiri, melainkan berada dalam kepenuhannya bersama yang lain. Berbisnis adalah melibatkan pihak lain, dengan seperangkat nalar dan pendasaran etis.

Dalam pengalaman Islam, berbisnis sebagai pelaksanaan perintah dan sikap keagamaan merupakan kenyataan. Nabi Muhammad Saw. dan sebagian besar para sahabat adalah pedagang dengan entrepreneurship kelas global. Etos ini melekat dalam diri umat, yaitu Islam adalah agama kaum pedagang, dilahirkan di kota dagang, dan disebarluaskan oleh pedagang ke seluruh dunia, termasuk ke Indonesia. Di samping menyebarkan Islam, para pendakwah juga mewariskan etos dan keahlian berdagang. Misalnya pada etnis Banjar (Kalimantan Selatan), Bugis (Sulawesi Selatan),

11 "Liberalisme" dalam http://id.wikipedia.org/wiki/Neoliberalisme, data diunduh pada 25 September 2006.

12 B. Herry-Priyono, "Neoliberalisme," Kompas, 15 Desember 2005. 
Gorontalo, Minang (Sumatra Barat), dan Pidie (NAD). Wilayah seperti Ceper (Klaten, Jawa Tengah), Kajen (Pati, Jawa Tengah), Kotagede (Yogyakarta, DIY), Laweyan (Solo, Jawa Tengah), Majalaya (Bandung, Jawa Barat), dan sebagainya menjadi bukti pasangsurut praktik bisnis umat. ${ }^{13}$

Posisi dan hubungan antar pelaku bisnis dengan penyelenggara negara menunjukkan hal yang strategis sekaligus menjadi piuh (biased) dengan kepentingan rakyat. Misalnya, ketika pemerintah merevisi UU No. 13/2003 tentang Ketenagakerjaan, pada April 2006. Agenda revisi tersebut memperlihatkan bahwa reformasi birokrasi yang menjadi tanggung jawab negara tidak berjalan optimal. ${ }^{14}$ Radikalisasi rakyat bersama pelaku bisnis terhadap negara menyoal minimnya keberhasilan pemerintah dalam mengatasi pengangguran. Kemapanan makroekonomi yang mampu meredam inflasi serta menstabilkan rupiah dan pasar keuangan tidak berdampak pada angkatan kerja (baru) dan bisnis riil. Data BPS 2006 melaporkan terdapatnya angka pengangguran terbuka pada bulan Februari sebesar 10,4\%, menurun dibandingkan November 2005 (11,2\%). Tetapi angka pengangguran terbuka masih meningkat, meskipun dengan tingkat yang semakin kecil, dari 10,3\% jika dibandingkan Februari 2005. ${ }^{15}$ Penciptaan lapangan kerja melalui pertumbuhan ekonomi menjadi sangat terbatas dan membutuhkan waktu dibanding permasalahan kerja dan bisnis itu sendiri.

Radikalisasi di atas juga menyoal kinerja negara untuk mengurangi kesenjangan pendapatan yang berdampak terhadap stabilitas politik maupun ekonomi. Skema yang direkomendasikan adalah membenahi sektor riil, membangun kelengkapan infrastruktur bagi usaha kecil dan menengah, menyusun serangkaian kebijakan

13 Lihat Hajriyanto Y. Thohari, "Robohnya Enterpreneur Santri Kita," Gatra, edisi khusus Oktober 2006, hal. 24-25.

14 Pemerintah beragumentasi bahwa revisi merupakan konsekuensi logis terbitnya Inpres No. 3/2006 tentang Paket Kebijakan Perbaikan Iklim Investasi pada Maret 2006. Revisi tersebut telah memicu radikalisasi rakyat bersama pelaku bisnis di tengah minimnya investasi dan masalah pengangguran. Lihat Kompas, "Revisi UU Ketenagakerjaan, Siapa Diuntungkan?” 8 April 2006.

15 Bambang Heru, "Struktur Spasial-Sektoral dan Ekonomi Indonesia," Kompas, 9 Maret 2006. Pertumbuhan penganggur yang berpendidikan SD atau tidak sama sekali, sangat fluktuatif karena bekerja pada sektor informal. Pengangguran didominasi kalangan berpendidikan SLTA (naik dari tiga juta orang pada 2001 menjadi 3,9 juta orang pada 2005) dan berpendidikan PT (naik dari sekitar 540.200 orang menjadi 708.200 orang). Dengan analisis kecenderungan, penganggur terdidik akan lebih besar, sementara yang berpendidikan rendah lebih sulit bersaing di pasar kerja. Pemerintah menargetkan pengurangan tingkat pengangguran dari 9,9\% pada 2004 menjadi 5,1\% pada 2009, sehingga dapat menurunkan tingkat kemiskinan dari 16,6\% menjadi 8,2\% dari jumlah penduduk pada 2009. 
yang berpihak pada pemberdayaan dan penguatan pelaku-pelaku lokal, serta bereaksi cepat terhadap segala keluhan. ${ }^{16}$ Sebaliknya, pelaku bisnis juga diharapkan untuk selalu membaca tanda-tanda jaman, mengedepankan praktik bisnis yang "layak," serta berorientasi pemberdayaan masyarakat.

Sementara itu, Konferensi Internasional Labour Organization di Busan, Korea Selatan, 29 Agustus - 1 September 2006, merekomendasikan "pekerjaan yang layak" (decent work). ${ }^{17}$ Yaitu perlunya penciptaan pekerjaan, pertumbuhan bisnis sekaligus perlindungan sosial pekerja, lingkungan manusiawi, kebebasan berorganisasi, serta memberi hak pekerja untuk melakukan tawar-menawar dengan majikan. Pekerjaan diperlukan untuk membuat rakyat bekerja dan melepaskan dari jerat kemiskinan. Pekerjaan harus bisa memberi pekerja tingkat upah sehingga ia bisa hidup di atas batas garis kemiskinan. ${ }^{18}$ Di samping itu, terdapat kecenderungan pemberdayaan masyarakat berbasis lembaga agama melalui penguatan ekonomi. ${ }^{19}$

Pertautan kepentingan antara GCG dan CSR dalam budaya neolib menegaskan posisi dan hubungan rakyat atau pranata sosial bersama pemangku kepentingan lain. Berdasarkan paparan di atas dapat dipahami bahwa; Pertama, pertautan kepentingan antara rakyat dan pelaku bisnis tidak selalu bersesuaian dengan kebijakan penyelenggara negara. Kedua, kebijakan penyelenggara negara tidak bersentuhan dengan kepentingan rakyat dan memunculkan tuduhan terhadap adanya kepentingan pelaku bisnis. Pandangan ini berdasar pada kasus penanganan pandemi flu burung, ${ }^{20}$ penyelesaian kumpur Lapindo Brantas, kebijakan impor beras, dan

16 Faisal Basri, "Daya Saing dan Peran Negara," Kompas, 3 Juli 2006.

17 Kompas, "Konferensi ILO, Asia Memerlukan Pekerjaan Layak," 31 Agustus 2006; Kompas, "Berikan Rakyat Pekerjaan,” 2 September 2006.

18 Posisi tersebut berlawanan dengan inti doktrin Thatcherisme dan Reaganisme: Kapitalisme neoliberal bukanlah menciptakan lapangan kerja yang layak, tetapi meraih keuntungan sebanyak mungkin. Lihat Kompas, "Dua Tahun WSSD, Tak Ada Waktu untuk Nostalgia," 29 Agustus 2004; Willy Aditya, "WTO: Perlawanan Antara Victoria Park dan Istana Merdeka," dalam http:// www.vhrmedia.net/index.php?id=view\&aid=187, data diunduh pada 25 September 2006.

Kerjasama ekonomi dan sosial antar-lembaga agama bisa mempercepat proses kerukunan dan kesejahteraan umat. Pemuka agama harus mendorong lembaga agama bekerjasama untuk menjawab masalah ekonomi dan ketidakadilan sosial. Lihat Kompas, "Peran pemuka Agama, Kerukunan Umat Beragama Lewat Kerja Sama Ekonomi,” 23 November 2006.

20 Rakyat berkepentingan menambah pendapatan, sementara pemerintah harus memusnahkan unggas-unggas tersebut. Retrospeksi GCG dan CSR membuktikan, ada kelalaian negara untuk mendampingi peternak unggas skala kecil sehingga virus flu burung leluasa menyerang dan membutuhkan pembiayaan publik yang besar untuk menangani. 
ketidakjelasan kebijakan transportasi publik. Penyelenggara negara menerbitkan kebijakan GCG dan CSR, sedangkan rakyat sebagai subjek pembayar pajak memilih jalan yang berbeda.

Kasus-kasus tersebut cenderung merugikan rakyat dalam keadaan yang tidak beradab. Standar Pelayanan Minimal yang diemban penyelenggara negara atau etika bisnis yang menjadi rujukan pelaku bisnis lebih kerap hadir secara karitatif dan filantrofis (kemanusiaan sesaat). Contohnya adalah kebijakan pembagian bantuan langsung tunai, pengobatan gratis, tataniaga kebutuhan sembilan bahan pokok, dan sebagainya. Artinya, kebijakan untuk melawan kemiskinan dalam laporan evaluasinya justru semakin menambah rakyat miskin.

Dengan menghampiri kebudayaan sebagai sistem pengetahuan menurut batasan yang diajukan Ignas Kleden, ${ }^{21}$ kebijakan GCG dan CSR belum mampu menjadi proses belajar sosial rakyat. Jika GCG dan CSR diasumsikan menjadi kebaikan bersama, posisi dan hubungan rakyat dalam budaya neolib seyogyanya menjadi kepentingan utama dan bukan untuk tujuan yang lain. Rakyat akan menderita jika tidak diberi kesempatan untuk tumbuh dan berkembang. Pelaku bisnis akan merugi jika rakyat pada akhirnya tidak mampu membeli produk barang dan jasa. Skenario gagal-negara menjadi nyata senyampang dengan menurunnya indeks kepercayaan warga terhadap kualitas layanan publik.

Untuk itu, dibutuhkan skema keadaban untuk menjaga rakyat agar tidak defisit. Skema berikut merupakan strategi budaya dalam konteks neolib di tengah kuatnya pengaruh perusahaan global (MNCs atau TNCs). Skema pertama adalah sikap terhadap neolib. Dalam konteks serbuan informasi tentang neolib, kita perlu untuk mengkaji firman Allah swt.:

"Hai orang-orang yang beriman, jika datang kepadamu orang fasik membawa suatu berita maka periksalah dengan teliti agar kamu tidak menimpakan suatu musibah kepada suatu kaum tanpa mengetahui keadaannya yang menyebabkan kamu menyesal atas perbuatan itu" (QS Al-Hujurat: 6).

Kita juga perlu melakukan retrospeksi dengan nasihat dari Ali bin Abu Thalib bahwa "Siapa yang merasa aman menghadapi zaman, maka zaman akan menghancurkannya. Siapa yang tinggi hati menghadapi zaman, maka zaman akan

21 Ignas Kleden, "Kritik Teori sebagai Masalah Ilmu Sosial," dalam A.E. Priyono dan Asmar Oemar Saleh, Krisis Ilmu-Ilmu Sosial dalam Pembangunan di Dunia Ketiga, (Yogyakarta: PLD2M, 1985), hal. 82. Kebudayaan sebagai sistem pengetahuan baru mampu menjadi orientasi, jika pengetahuan yang ada menjadi sistem makna. 
merendahkannya. Siapa yang bersandar pada tanda-tanda jaman, jaman akan menyelamatkannya." Pengenalan terhadap tanda-tanda jaman neolib ini, yang menjadi pendasaran untuk membaca kembali kebijakan GCG dan CSR.

Budaya neolib yang mewartakan kuasa pasar merupakan energi besar perubahan yang permanen dan kadang tidak terencana, dengan percepatan yang tinggi dan tak terkendali. Dampaknya adalah adanya rakyat atau pranata sosial yang mampu beradaptasi dan yang tertinggal dengan rasa frustasi dan keputusasaan. Semuanya mengalami proses "penuaan" atau "pelapukan" karena merasa tertinggal oleh perubahan. Jika tidak berbenah diri akan mengalami keadaan yang usang, lapuk, kadaluwarsa, dan lumpuh. Untuk bertahan diri dan sejajar dengan yang lain, rakyat harus mempertahankan diri atau beradaptasi untuk keunggulan komparatif dan kompetitif.

Adaptasi merupakan proses penyesuaian terhadap lingkungan tertentu. Untuk beradaptasi, dibutuhkan peta/skenario dewasa ini dan sekaligus anatomi masa depan, dengan prinsip kebolehjadian dan kemungkinan alternatif jawaban. Struktur adaptasinya mengacu pada penyiapan rakyat guna menghadapi masa depan, dengan riset masa depan, untuk mengakomodasi kehidupan itu sendiri. Riset digunakan untuk menyusun peta atau merangkai skenario, sedangkan peta atau skenario untuk mengetahui anatomi masa depan yang akan dihadapi. Ketepatan dan kebajikan dari peta atau skenario diharapkan mengurangi kesalahan pada proses belajar sosial. Dengan demikian, pengambilan keputusan saat ini merupakan aset, dengan tidak menutup diri terhadap reformasi, mempunyai fleksibiltas tinggi serta wawasan yang progresif.

Skema kedua adalah bahwa pilihan demokrasi sudah diharuskan oleh kondisikondisi ekonomi-politik dewasa ini. ${ }^{22}$ Artinya, rakyat niscaya berposisi sebagai pembeli yang berdaulat (buyer soveregnity). Posisi sebagai pembeli yang berdaulat terhadap tawaran penjual merujuk pada sabda Nabi Muhammad saw.:

"Penjual dan pembeli mempunyai hak pilih selama keduanya belum berpisah. Jika keduanya jujur dan memberikan penjelasan, maka akan diberikan berkah kepada keduanya dalam jual-beli mereka. Dan jika keduanya saling berdusta dan menyembunyikan, maka akan dihapuskan berkah jual beli mereka" (H.R. Bukhari dan Muslim).

22 Adopsi dari "Economic Base of Democracy Imperative” yang diajukan Daniel Dhakidae, Dasar Ekonomi Bagi Keharusan Demokrasi, Pengantar Diskusi di Yayasan Perpustakaan Hatta, Yogyakarta, 12 Agustus 1991. 
Tanpa posisi ini, pelaku bisnis dan penyelenggara negara akan merugi, berkahnya akan dihapuskan, serta cita-cita GCG dan CSR untuk kemaslahatan rakyat menjadi involutif. Jika pendapatan rakyat hanya cukup untuk membeli kebutuhan pokok sehari-hari dan tidak mempunyai sisa untuk berbelanja yang lain, berarti rakyat tidak mampu berposisi sebagai "pasar" yang akan membeli produk barang dan jasa bisnis. Bagi pelaku bisnis, belanja (konsumsi) merupakan kekuatan yang menggerakkan sektor riil. Keadaan sebaliknya adalah jika terjadi ketiadaan atau ketidakmampuan untuk berbelanja sehingga melumpuhkan pasar dan penyelenggara negara.

Senyatanya, bahkan dengan meluasnya gerakan penyadaran konsumen, posisi penjual dan pembeli yang berdaulat niscaya tetap diperjuangkan. Hal ini untuk menjaga agar "pembeli yang berdaulat" -baik sebagai rakyat, pelaku bisnis, dan penyelenggara negara- tidak merugi. Dalam kasus ini, sikap tidak berbelanja untuk jangka waktu tertentu merupakan contoh perlawanan terhadap pasar. ${ }^{23}$

Skema ketiga adalah sikap terhadap "memetic engineering," yaitu strategi budaya melalui "meme" (gagasan) yang menjadi unsur dasar budaya neolib. Terdapat gagasan untuk menyeragamkan nalar guna memudahkan pelaku bisnis menghasilkan produk barang dan jasa yang seragam untuk pasar yang diseragamkan. Atas nama "pasar tidak pernah salah," pelaku bisnis membentuk citraan tertentu dengan penghormatan kedaulatan konsumen: Bahwa konsumen mempunyai nalar, latar belakang pendidikan, dan kebebasan memilih. Pengetahuan konsumen dan produsen sama, pengetahuan konsumen di seluruh dunia dari masing-masing status ekonomi sama, serta hak dan kewajiban sama dengan konsumen. ${ }^{24}$ Strategi budaya ini adalah penyediaan alternatif terhadap citraan neolib yang selalu tampil cantik berkat iklan yang berbasis riset, sistem pendidikan, politik, dan prioritas terhadap sektor finansial.

Laporan keuntungan pebisnis waralaba makanan cepat-saji, kecenderungan belanja pemeliharaan kesehatan, tawaran kondominium yang eksklusif, untuk menyebut beberapa contoh, merupakan praktik budaya neolib. Nalar ini bahkan mampu mengakomodasi kearifan lokal, misalnya lewat proyek romantisme

23 Komunitas "The Compact" melakukan praktik puasa belanja barang baru selama setahun, kecuali makanan, produk kebersihan diri seperti pasta gigi atau sabun, serta obat-obatan. Lihat Jawa Pos, "Kelompok Pencinta Lingkungan "The Compact" Sukses Stop Konsumtif," 4 Januari 2007. Di kalangan aktivis pro-konsumen berkembang tindakan tidak mengkonsumsi barang dan jasa yang dihasilkan perusahaan neolib, dengan menolak free trade sembari mempraktikkan fair trade.

24 Hira Jhamtani, "Kuasa Korporasi: Penjajahan Pikiran dan Ruang Hidup," dalam Wacana Edisi 19 Tahun VI, 2005, hal. 6. 
"keaslian" suatu budaya lokal sebagai latar iklan perusahaan. Negasi terhadap "memetic engineering" adalah dengan membangun nilai-nilai kerakyatan yang sejalan dengan kemajemukan bangsa agar keberagaman diterima sebagai sebuah kekayaan dan tidak melulu dipertentangkan.

Membangun nilai-nilai kerakyatan dalam konteks neolib adalah menyegarkan pemahaman tentang konsekuensi dari nafsu "cinta harta" (bubu al-dunya). Cinta harta adalah praktik untuk mengakumulasi modal dan margin keuntungan serta mengabaikan rakyat itu sendiri. Pesan Al-Quran dalam konteks ini adalah, "Tahukah kamu siapakah orang yang mendustakan agama? Dialah orang yang menghardik anak yatim dan tidak mau mengusahakan secara serius persoalan makan (kebutuhan dasar) bagi orang-orang miskin". ${ }^{25}$ Kebutuhan dasar sebagai hak dasar rakyat merupakan kebijakan prioritas, baik dengan skema GCG dan CSR atau tidak. Jika skema tersebut justru menjadi tindakan kemanusiaan semu, atau menjadi ketergantungan baru, rakyat sendiri yang justru akan menolaknya.

Ketiga skema keadaban tersebut mengapresiasi model konvensional, menyiapkan model transisional, dan menyelenggarakan proses belajar sosial untuk model ideal. Ketiga skema mengagendakan serta mendudukkan budaya agung neolib dalam konteks dan kepentingan rakyat, tidak lebih dan tidak kurang.

\section{Penutup}

Prinsip responsibility dari GCG membawa konsekuensi tanggung jawab bagi pelaku bisnis tentang peran serta perusahaan dalam mewujudkan tanggung jawab sosial. Karena pada dasarnya kekuatan CSR terletak di dalam pemberdayaan masyarakat agar berpotensi sebagai konsumen sekaligus sasaran pelaku bisnis.

Pertautan kepentingan antara GCG dan CSR dalam budaya neolib menegaskan posisi dan hubungan rakyat atau pranata sosial bersama pemangku kepentingan lain. Berdasarkan paparan di atas dapat disimpulkanbahwa pertautan kepentingan antara rakyat dan pelaku bisnis tidak selalu bersesuaian dengan kebijakan penyelenggara negara. Selain itu, kebijakan penyelenggara negara tidak bersentuhan dengan kepentingan rakyat dan memunculkan tuduhan terhadap adanya kepentingan pelaku bisnis. Untuk itu, dibutuhkan skema keadaban untuk menjaga rakyat agar tidak defisit. Skema ini merupakan strategi budaya dalam konteks neolib di tengah kuatnya pengaruh perusahaan global (MNCs atau TNCs) 
Skema pertama adalah sikap terhadap neolib. Kedua, pilihan demokrasi sudah diharuskan oleh kondisi-kondisi ekonomi-politik dewasa ini. Dan ketiga, sikap terhadap "memetic engineering," yaitu strategi budaya melalui "meme" (gagasan) yang menjadi unsur dasar budaya neolib.

\section{DAFTAR PUSTAKA}

"Liberalisme". 2006. Dalam http://id.wikipedia.org/wiki/Neoliberalisme, data didouload pada 25 September.

Aditya, Willy. 2006. "WTO: Perlawanan Antara Victoria Park dan Istana Merdeka" dalam http:/ / www.vhrmedia.net/index.php?id=view\&aid=187, data didownload pada 25 September.

Al Qur'an dan Terjemahannya.

Alijoyo, FA. 2004a. "Trilogy of Governance (I) Corporate Governanc” dalam Republika, 10 Maret.

.2004b. “Trilogy of Governance (II)" dalam Republika, 5 Mei.

Basri, Faisal. 2006. "Daya Saing dan Peran Negara" dalam Kompas, 3 Juli.

Buchori, Mochtar. 1994. Pendidikan dalam Pembangunan, Yogyakarta: Tiara Wacana kerjasama dengan IKIP Muhammadiyah Press.

Daniri, Mas Achmad. 2004, "Membudayakan 'Good Corporate Governance” dalam Kompas, 15 April.

Dhakidae, Daniel. 1991. "Dasar Ekonomi Bagi Keharusan Demokrasi” dalam Pengantar Diskusi di Yayasan Perpustakaan Hatta, Yogyakarta, 12 Agustus.

Heru, Bambang. 2006. "Struktur Spasial-Sektoral dan Ekonomi Indonesia" dalam Kompas, 9 Maret.

Jalal. 2006. "Menimbang CSR secara Rasional" dalam Kompas, 16 September.

Jawa Pos. 2007. Kelompok Pencinta Lingkungan “The Compact” Sukses Stop Konsumtif, 4 Januari.

Jhamtani, Hira. 2005. "Kuasa Korporasi: Penjajahan Pikiran dan Ruang Hidup" dalam Wacana Edisi 19 Tahun VI. 
Kleden, Ignas. 1985. "Kritik Teori sebagai Masalah Ilmu Sosial” dalam A.E. Priyono dan Asmar Oemar Saleh, Krisis Ilmu-Ilmu Sosial dalam Pembangunan di Dunia Ketiga, Yogyakarta: PLD2M.

Kompas. 2004. "Dua Tahun WSSD, Tak Ada Waktu untuk Nostalgia” 29 Agustus. . 2006. "Konferensi ILO, Asia Memerlukan Pekerjaan Layak” 31 Agustus. . 2006. "Peran pemuka Agama, Kerukunan Umat Beragama Lewat Kerja Sama Ekonomi” 23 November.

_.2006, "Revisi UU Ketenagakerjaan, Siapa Diuntungkan?” 8 April. - 2006. "Berikan Rakyat Pekerjaan” 2 September.

Priyono, B. Herry. 2005., "Neoliberalisme” dalam Kompas, 15 Desember. -2006. "Ekonomi dalam Lumpur" dalam Kompas, 4 Oktober.

Setiawan, Bonnie. 2004. "LSM sebagai Kekuatan Sosial Baru” Kompas, 17 April.

Subagyo, Agus dan Imam Samroni (ed) .2005. Hasanuddin Yusuf: Meretas Jalan Menuju Pengabdian Bagi Pemuda, Yogyakarta: LSKPD.

Supomo, Sita. 2004. "Corporate Social Responsibility (CSR) dalam Prinsip GCG” dalam Republika, 20 Oktober.

Thohari, Hajriyanto Y. 2006. "Robohnya Enterpreneur Santri Kita" dalam Gatra, edisi khusus Oktober. 